\title{
Ancient Sri Lankan Economic Systems
}

\author{
Manik Jayasundera \\ University of Peradeniya, Sri Lanka.
}

\begin{abstract}
The Greek philosopher Father of History Herodotus realized the value of studying the past as not how it happened but what happened. It is also a critical analysis that shows the human development; a phenomenon that changes rapidly and a methodical study that helps to acquire knowledge. The strategies implied by Sri Lankan aristocrats who lived in the ancient society to maintain their existence safely and in a balance manner, is the philosophy and all the Victories and Failures are involved in the Present! Moreover, both the ordinary vendor and the Mayor or Tax Collectors were advised wisely by the Kings, legitimate heir and clergy to do the needful. You can obtain some experience by looking into the ancestral methods they practiced in trade and economy which are similar to the present situation. As trade becomes strong against new challenges and when the immunity is created through society the historical heritage and perception become the same. Therefore, it is essential to study their nature of the contribution to render services to trade and economy, which has been complied, based on that standpoint. This strengthens minds for criticizing the everlasting conversation of past to present trade and economy and opens gateways to other activities as well. Whilst studying, a person is well disciplined, improves his own ability, learns human ideologies other than their own ways, gains access to inter relationships and most importantly distinguish associate!
\end{abstract}

Keywords: ancient economic system, trade, modern economic system, Feudal System.

JEL Classification: P00, P4, F1.

(C) The Author, 2017. This article is published with open access at ARMG Publishing.

\section{Introduction}

When examining the ancient trade and economy of Sri Lanka, it is important to touch inscriptions, numismatics, literary sources of local and foreign calligraphy that have revealed most statistics and clear evidences of trading and economical activities. Those foreign literary sources are renowned as Travel Record Books of the respective traders and explorers of China, Rome, Greece, Arabia and India with relevance to their trading and economical activities. As Sri Lanka maintained foreign affairs since Before Crist with India, it reveals the fact on inculcating Indian base of trading and economy through introduction of Buddhism to the country during the period of the great Indian Emperor Ashok of 273 B.C. According to the Emperor's doctrine of trade, economy and administration, the foreign affairs were only handled by Royalists; the inland trading and economy were based on Barter System by exchanging goods to goods as the ordinary country men were not granted permission to use numismatics for any purpose. From ancient history of 2600 years, economy and trade mean the production of agriculture and industry. Further, to develop the trade and economy, country was divided in to many provinces with specific borderlines and aristocrats appointed as the regional rulers for maintenance and to grand state patronage to prolong sovereignty. The farmers and peasants were well looked after by chieftains as the country future was depending on their productions. In accordance to the most rock inscriptions reveal the annotation in variety of commodities viz: salt, rice paddy, cotton drapery, earthenware, metal products, fresh water and brackish water fish in exchange under the local Barter system. According to Weherakema-Hambanthota inscription the hand loom viewers were being special for international trading, they were granted special state patronage who were known as "Thanthuwaya". While "Periyankulama and Thonigala" rock inscriptions reveal the facts of trading and respective commodities, "Badulla" pillar inscription finds information of Hopithigamuwa town as the trading center for the collection and distribution of goods and trading units, when "Godawaya" pillar inscription have professed the types of taxes and its collection in numerous ways per annum. There is enough to prove that there were a considerable number of foreign traders in the country and different trade organizations according to "Bowathegala" inscription I Southern Province. Those trading organizations were known as "Kaboja Maha Pugiya". And those vendors were from Kambodia and Afghanistan. It was discovered a metal stamp in Southern region which was belong to foreign traders who were known as "Nanadesin and Aynirwaru" who were trading during the period of $11^{\text {th }}-13^{\text {th }}$ centuries. According to Thonigala inscription there were specific three seasons for paddy cultivation as the authority expects country to be self-sufficient and excess to be exported for the purposes of maintenance of foreign and local trading. The pillar inscription of "Medirigiriya" states if anyone disturbs or violates state 
rules of contribution towards the economy he would suffer in his next birth according to their believes. This clears that the rulers have imply the basics of creed - as trading, agriculture and cottage industry are the base of development and existence of the country. Other than three harvesting seasons for paddy cultivation, there were other productions, which have been contributing from time to time. The total production was collected by aristocrats of the respective regions for their easy reference of taxations. This collection of production would be divided in to three equal portions. One third of the portion was kept by peasants for their family use and future trading activities. The other two thirds of the production was collected by the chieftains in order to wave economy activity and for their personal use as well. The chieftains would keep their portion of one third and the balance one third would be given to the existing ruler for Royal purposes. The collected royal portions of all products would be kept in warehouses and granaries for future evenly distribution whenever it is necessary. While enjoying the state the King would donate or distribute the goods from time to time according to state disaster situations called droughts, war crisis or any natural disasters in order to maintain country economy under any circumstances in all spheres.

\section{What is Feudal System?}

This special trading activity is renowned as "Feudal System". Under the Feudal system Kings would bear the total land tenure of the state and legitimate heir would be administrating their given territories in order to safeguard peasants, develop the production and to collect taxes for the state. The state patronage was granted for trading and agriculture as the Feudal system was exclusively charitable to the nation and state economy. Therefore the production under feudal system and trading through Barter system were highly esteemed and well maintained by all legitimate heir in order to control the economy and annual maintenance of the four fold military services too. The second Kingdom of Sri Lanka was Polonnaruwa, and there first local ruler was great King Vijayabahu I in 1070 A.D. In accordance to the development and safety of economy he married a princess of Kalinga state of India and maintained international trading with most South Indian states and Burma/Myanmar state too. In order to pacify King Vijayabahu I, Burma state have gifted vessels lords of goods to maintain rich economy standard through international trading with them. This transaction would have set a platform for the existing trade and economy as Sri Lanka was in the peak of wealth and close international relationship with them. During the period of Great King Parakramabahu 1 of Polonnaruwa Kingdom in 1153 A.D. Sri Lanka was renowned as "The Granary of the East" for being exporting rice paddy to many South East Asian countries and earning much of foreign exchange which proves high standards of country economy and production towards trading. The information of economy and international trading of Polonnaruwa Kingdom are found in epigraphy of "Devanagala and Sangamu temple" rock inscriptions. Apart from agriculture, the production of industries also have contributed immensely for the development of country economy. The special areas of contribution were done through iron smith, copper smith and handloom weaving etc. The excess production of iron was handed over to the King as most of those productions were weapons and tools which belonged to warfare. The caste of iron smith was granted facilities by the Central Government from time to time as they gave the helping hand in producing weapons for military. Moreover, industry peasants and vendors would exchange their products of plough, mammoth, sickle, hammer and knife for their general rations to viz: rice paddy, grams, green grams, sesame, salt, tamarind, clothing, earthenware or bare essentials to prove that the economy state was advanced and easy reference to exist. There were some trading groups that have helped in collecting and distributing called "Poogaya", when traders were named as "Wanija". As trading was one of the important profession in the society king have taken steps to impose the law in order to prevent frauds afoot in the trading center such as: twice the amount of taxes to be charged from those who do their business without showing officials, weighing units should be used only upon government approval, areca nuts and beetles should be sold under a thatched roof, heavy taxes to be charged for trading on full moon days. The former trading and economic system is simple to assimilate without using numismatics in order to indulge vendors. Inevitably, rulers would distribute Royal gifts to vendors and peasants to reconfirm the sovereignty and to re continue with their trading and economical activities for future developments. In the meantime, the King would please the noble syndicate in all regions with transaction lands, property or numismatics for them to maintain the economy and trading standards effectively and efficiently with a view of a favor to Central Government. Though local trading and economy was controlled by the respective chieftains, the foreign affairs were only handled by the Kings and have paid the imported goods mostly by coins but seldom valuable gifts accordingly. This law and tradition would have controlled the anti-social behavior of people for the benefit of the society and economy. 


\section{The development of trade and economy in ancient Sri Lanka}

The information on trade was also revealed in most local and foreign chronicles belonged to $2^{\text {nd }}$ Anno Domini and thereafter. The foreign vendors who sailed across Indian Ocean through silk route have emphasized the facts of advanced level of trading and it was said "Trading with Hela Diva/ Sri Lanka paves the way to a Jackpot throwing". According to philosopher Aristotle's book "De Mundo", it would reveal the fact that Sri Lanka was trading with North-West India since Before Crist; the Greek Minister of India chamber Megasthine's book "Indica" has mentioned that Sri Lanka was in the peak of international trading during the period of King Chandra Guptha of India; the Roman Pline's 'Naturalis Istoria have stated the high quality of goods, and "Periplus of Erithrean Sea" chronicles of $1^{\text {st }}$ A.D. have mentioned the export commodities viz: gems, peals and cotton drapery. The geographer Alexandrian Claudius Ptolemy, who lived in 90 A.D. to 168 A.D., had clearly explained in his book of "Into Geography/Approach to Geography" the contribution to international trading by Sri Lanka, its location along the ancient silk route, international trading harbors which belonged to Sri Lanka and valuable services rendered for trading in the past. As Sri Lanka was famous for trading mainly dealing with Arabian Peninsula, Ptolemy has marked Sri Lanka in his world map where the island is more towards to western cost of India and much of a bigger land than India. This proves that he was under the impression (as he never visited Sri Lanka) that island is being wealthy and close proximity to Arabia and a vast land to produce much of goods for international market. According to the writing of Roman Procopious' "Persian War" and Cosmos' "Topographia Christiana" emphases the importance of Sri Lanka being the center of trading process in the Indian ocean from East to West. The Asian epitomes talk on the epoch and commodities as: the Arabian traveler Sulaiman of $9^{\text {th }}$ A.D. had stated in his travel record book that "Serendib" (Sri Lanka) is a paradise for trading for a longer period. Arabian Abu Zaid's book "Silsilath Al Thwarine" says the close relationship between Arab and Sri Lanka, and have imported high quality carpets and glassware from them. The Arabian who sailed often to East was Ibn Batuta who has mentioned of long standing foreign affairs through trading and the trust among Sri Lanka rulers and Arabians. The Chinese traveler Reverend monk Fa Hien have toured around the island and written about epitomes in regard to epoch and different import and export commodities as well, stating that the trading and economy status were highly esteemed by European and Asian countries. Moreover, the Chinese travelers $\mathrm{Hu}$ Evoh, Ith Sin and Chao Ju Quao have also mentioned on international trading of Sri Lanka that is reliable and have maintained a strong relationship with Far East countries as well. According Indian calligraphy author Kautilya's book of economy "Artha Shastra" states on Sri Lanka's ancient trading, its wealth and high standard of economy too. Kautilya has named Sri Lanka as Thamraparnee and Paara Samudra as the island was famous for not being to imposture in any sphere. This island is also renowned for international trading of gems, elephants, tusks, ivory items and spices to most European countries and Asian countries. Those commodities were exported through special trading ports named Manthei, Godawaya and Gokanna, which are presently known as Manner, Hambanthota and Trincomalee respectively. Trincomalee is one of the natural, larger and deepest harbours in Asia, which is known as "Bottomless".

The base of present condition of trade could be observed through critical analysis of cultural activities such as ancient local calligraphy. These writings will reveal the definitions of trade and trading items acting differently in different reigns. On reading the local chronicles there are the methodical study of who the ruler, what has he done and his contribution towards the gate way of economy. The oldest chronicle of Sri Lanka is known as "Deepawamsaya" which gives the details of royal patronage for agriculture. But the most accurate chronicle viewed on trade and economy is the later authentic version of historical events on "Mahawamsaya" of $6^{\text {th }}$ A.D. The author of Mahawamsaya, priest Venerable Mahanama who lived in the Kingdom of Anuradhapura period had come across with diverse facts, ideologies and opinions on ancient shifting cultivation, trade and economy patterns where critical sense got developed. Apart from that the chronicles of "Dalada Siritha, Data Wamsaya, Poojawaliya and Saddharma Rathnawaliya" also have mentioned the goods that have exchanged under Barter system in the past. The writing of Dalada Siritha gives the information of the first collection of harvest of the year, have been donated in the name of Buddhism and the rest have handed over for trading purposes. This proves that at any event of the society it had a special respect and devoted for the state religion. Even at present, it is the same practice of reserving the fresh portion by devotees before Buddhism.

This paradise is being located much closer to Equator where Arabian and European traders found easy to sail along Trade Winds within the two Tropics of Cancer to the North and Capricorn to the South of Equator. Trading along silk route on land and across the Indian Ocean, this island is the centre as a stopover for resting and buying goods in. The famous North Indian chronicles viz: "Mahabharatha, Ramayanaya, Rajatharangeni and Lankawathara" reveal the facts on exporting cotton drapery and different types of gems to India which 
were in high quality and expensive. According to South Indian calligraphy "Divyawadaan, Skandapurana, Silappadikaram, Paththupattu and Pattinepalai" the state on Sri Lanka's trading activities and exported commodities are under state patronage. Further to study on import-export activities, it is clear that the Central Government have taken steps to settle the cost of imported items by paying through the existing coins. There are different types of coins, which were used in different reigns in respect of different eras and Kings. The oldest numismatic which was used is known as "Has Ebu" and it was introduced by Northern Indian merchants and the medium was silver. Some of the other coins are identified as "Kahapana, Aka, Dharana, Purana, Lakshmi, Swasthika, Tusker and "Ranmasu" where the medium was gold. During the Polonnaruwa reign of King Vijayabahu I gold coins were used and in times of King Parakramabahu I silver coins were used. In the reign of Kotte Kingdom King Parakramabahu VI copper coins were used. The gold hooks were in use as coins during the Kingdom Kandy in Sri Lanka. To use such different medium to press their numismatics in different periods shows that it was wealthy and high standard of economy in the past. Later in excavations there found silver coins from South India which belonged to King Parakramabahu I, Chinese coins near Trincomalea harbor, most abundant copper Roman coins and Arabic coins near Manner harbor that clearly shows how in the ancient time Sri Lanka practically applied the usage which was essential in economic affairs to be successful. When exporting rice paddy it was said to be used the indigenous measuring of space from smallest "Laha" to largest "Karisa" (ancient local system of measuring). By measuring according to Karisa Sri Lanka has exported mostly spices viz: cinnamons, coriander, cloves, cardamoms, fenugreek, nutmeg, dill, chilly, nut, beetles and mustard. To measure weight of Gems it has been used "Veeha" to "Swarna/Pala" which were officially approved by the Central Government. Some of the kinds of gems under the export items were Cat's Eye, Moon stone and Blue Sapphire mainly to the countries in Europe and Arab.

\section{Conclusion}

According to the above mentioned evidence of inscriptions, local and foreign chronicles, travel record books, numismatics clearly show how the ancient Sri Lanka practically applied the usage which was essential in trade and economic affairs to be successful. By considering these evidences neither detractor nor deniable sources can disprove as there were other destinations which were in the highest peak of foreign affairs or international trading and which have served foreign vessels with a close touch of friendship and entrust. However, it is immensely important to know the economy and trading activities were in the center of attraction of all countries and this island was one of the richest states in the Indian Ocean in the past.

\section{Acknowledgement}

The Panel of Writers

Educational Publications Department

History New Syllabus 10 (2014) \& Old Syllabus 10 (2006)

Isurupaya, Battaramulla, Sri Lanka

www.thaksalawa.moe.gov.lk

\section{References}

1. History Text Book. Grade 10 (New Syllabus 2014). Lesson 01, p. 6; Lesson 04, pp. 45 - 53; Lesson 05, p. 72; Lesson 06, pp. 80 - 82. Available at www.doenets.lk

2. History Text Book. Grade 10 (Old Syllabus 2006). Lesson 01, pp. $01-07$; Lesson 03, p. 27. Available at (www.doenets.lk )

3. Forster, E.S. (1914). Aristotle's De Mundo. Oxford, At the Clarendon Press.

4. Cosmas Indicopleustes (2010). The Christian Topography of Cosmas, an Egyptian Monk: Translated from the Greek, and Edited with Notes and Introduction. Cambridge University Press. ISBN 978-1-108-01295-9.

5. Guthart, Mikaël Gómez (2017), Histoire Naturelle de Pline l'Ancien, Paris, La Nouvelle Revue Française, (lire en ligne [archive]).

6. Procopius (500). History of the Wars, Volume I, Books 1-2. (Persian War). Available at http://www.hup.harvard.edu/catalog.php?isbn=9780674990548 